Vol. 3 No. 1 February 2019

\title{
Potensi Ekstrak Daun Bandotan (Ageratum conyzoides L.) Sebagai Spray Untuk Pemulihan Luka Mencit Diabetik Yang Terinfeksi Staphylococcus aureus
}

\author{
Erra Ericha Safani ${ }^{1}$, Wanodya Ayu Chandradevi Kunharjito ${ }^{1}$, Alfiyan Lestari ${ }^{1}$, Erlix \\ Rakhmad Purnama ${ }^{*}$ \\ 1 Universitas Negeri Surabaya, Surabaya, Indonesia \\ *erlixpurnama@unesa.ac.id
}

\begin{abstract}
Ageratum conyzoides L. leaf has the main compound of flavonoids and alkaloids that contribute to accelerate the healing process of diabetic ulcers with Staphylococcus aureus infection that can affect the quality of life of patients. This study aims to test the leaves of Ageratum conyzoides L. on the recovery of diabetic ulcers of mice infected with Staphylococcus aureus. The method used is the extraction of Ageratum conyzoides L leaves as the material of spray 15\%, induction of diabetic compound (Alloxan monohydrate), length wound $(1 \mathrm{~cm})$ and bacterial infections, and spray application with 1 times daily frequency, 2 times daily, 3 times a day for 9 days. The results showed that the lenght of wounds in group $A, B, C, D$, and $E$ were 0,$5 ; 0,8 ; 0,4 ; 0,2 ; 0,0$. The administration of Ageratum conyzoides L. spray which has active flavonoide substances, alkaloid substance, and saponin substances has an effect on decreased length of diabetic wounds and restoration of dermis tissue structure (increases epithelial cells proliferation, initiates fibroblast cells, and stimulates type 1 collagen). Spray treatment 3 times a day (group E) was more influential than the other treatments, which experienced wound closure in 9 days. Thus, Ageratum conyzoides L. leaf spray is potential for therapy of diabetic ulcers infected with Staphylococcus aureus.
\end{abstract}

Keywords: Spray, Ageratum conyzoides L, Diabetic Ulcers, Staphylococcus aureus

\begin{abstract}
ABSTRAK
Daun Ageratum conyzoides L. memiliki senyawa utama flavonoid dan alkaloid yang berkontribusi dalam mempercepat proses penyembuhan ulkus diabetikum dengan infeksi bakteri Staphylococcus aureus yang dapat mempengaruhi kualitas hidup penderita. Penelitian ini bertujuan untuk menguji potensi daun Ageratum conyzoides L. terhadap pemulihan luka diabetik mencit terinfeksi bakteri Staphylococcus aureus. Metode yang digunakan yaitu dengan ekstraksi daun Ageratum conyzoides L. untuk pembuatan spray 15\%, induksi senyawa diabetik (Alloxan monohydrate), pembuatan panjang luka $(1 \mathrm{~cm})$ dan infeksi bakteri, serta pengaplikasian spray dengan frekuensi pemberian 1 kali sehari, 2 kali sehari, 3 kali sehari selama 9 hari. Hasil penelitian menunjukkan panjang luka pada kelompok A, B, C, D, dan E berturut-turut adalah 0,5; 0,8; 0,4; 0,2; 0,0. Pemberian spray Ageratum conyzoides L. yang memiliki zat aktif flavonid, alkaloid dan saponin berpengaruh pada berkurangnya panjang luka diabetik dan pemulihan struktur jaringan dermis (meningkatkan proliferasi sel epitel, menginisiasi sel fibroblas, dan menstimulasi kolagen tipe 1). Perlakuan spray 3 kali sehari (kelompok E) lebih berpengaruh dibandingkan dengan perlakuan yang lain, yaitu mengalami penutupan luka dalam 9 hari. Dengan demikian, spray daun Ageratum conyzoides L. berpotensi untuk terapi ulkus diabetikum yang terinfeksi Staphylococcus aureus.
\end{abstract}

Kata Kunci: Spray, Ageratum conyzoides L., Luka Diabetik, Staphylococcus aureus 


\section{PENDAHULUAN}

Indonesia merupakan negara tropis yang memiliki potensi besar dalam kekayaan alamnya. Terdapat 30.000 jenis tanaman di Indonesia, 7000 diantaranya merupakan tanaman obat, dan hanya 2500 tanaman yang dijadikan sebagai obat. Ageratum conyzoides L. atau yang dikenal dengan bahasa lokal sebagai "Bandotan" termasuk dalam salah satu tumbuhan yang memiliki khasiat sebagai obat. Keberadaan tumbuhan ini sangat melimpah. Tumbuhan ini memiliki banyak manfaat di bidang kesehatan salah satunya penyembuhan luka (Igafur et al, 2016)

Permasalahan kesehatan yang mendunia saat ini adalah penyakit diabetes melitus yang memiliki peran penyebab kenaikan angka kematian di dunia. World Health Organization menyebutkan bahwa Indonesia menempati peringkat ke-7 negara penyandang penderita diabetes melitus, dan diperkirakan pada tahun 2030 mendatang diperkirakan akan terjadi peningkatan penderita mencapai 21,3 juta penderita (Kemenkes RI, 2017).

Diabetes melitus kronis dapat menyebabkan kejadian komplikasi yang berujung pada neuropati dan iskemia yang kemudian bermanifestasi pada ulkus diabetik (Smeltzer dan Bare, 2008). Penderita ulkus kaki diabetes di Indonesia sekitar 15\% dengan angka amputasi mencapai 30\% dan angka kematian 32\%. Permasalahan ini dapat mempengaruhi kualitas hidup serta kondisi ekonomi bagi penderita (Hastuti, 2008).
Penggunaan obat sintetis untuk terapi ulkus diabetik masih belum bisa sesuai dengan harapan. Selain efek yang ditimbulkan, biaya yang diperlukan juga mahal. Penderita ulkus diabetik saat ini lebih cenderung memilih alternatif obat dengan biaya yang terjangkau dan dapat memberikan efek terapeutik.

Staphylococcus aureus merupakan salah satu jenis bakteri yang dapat menginfeksi luka. Luka adalah kerusakan pada struktur anatomi kulit yang menyebabkan terjadinya gangguan kulit. Bakteri Staphylococcus aureus dapat ditemukan pada permukaan kulit sebagai kuman flora normal. Bakteri Staphylococcus aureus juga sering terdapat pada pori-pori dan permukaan kulit, kelenjar keringat dan saluran usus. Staphylococcus aureus dikenal sebagai mikroorganisme patogen yang dihubungkan dengan berbagai sindrom klinis (Arianingsih et al, 2015).

Analisis fitokimia Ageratum conyzoides L. yang telah dilakukan oleh Amadi et al (2012) menunjukkan bahwa senyawa utama yang ada di dalam tanaman Ageratum conyzoides L. yaitu alkaloid dan flavonoid terakumulasi pada daunnya. Aktivitas alkaloid dapat meningkatan proliferasi seluler pada lokasi luka yang disebabkan oleh sintesis kolagen yang mengalami pengendapan. Alkaloid ini telah berkontribusi secara luas terhadap proses penyembuhan luka dengan cara regenerasi dermal dan epidermal dini, memiliki efek positif terhadap proliferasi seluler, pembentukan jaringan granular dan epitelisasi (Gupta et al, 2008). 
Penelitian lain yang telah dilakukan oleh Mahibalan et al (2016) menunjukkan bahwa formulasi obat yang mengandung senyawa alkaloid dapat mempercepat penyembuhan luka potensial. Oleh karena itu penelitian ini bertujuan untuk menguji daun Ageratum conyzoides L. terhadap pemulihan ulkus diabetikum mencit terinfeksi bakteri Staphylococcus aureus.

\section{METODE}

Penelitian ini dimulai pada bulan April Agustus 2018. Lokasi penelitian dan pengambilan sampel daun tanaman Ageratum conyzoides L ialah di Banyuurip Ujungpangkah Gresik. Sampel yang diambil ialah bagian daun pada seluruh nodus. Untuk hewan uji, digunakan mencit jantan usia 8-10 minggu yang didapatkan dari Pusat Veteriner Fatma Surabaya, sementara itu pengujian sampel di Laboratorium Fisiologi Jurusan Biologi Fakultas Matematika dan IPA Universitas Negeri Surabaya. Pengambilan sampel dilakukan pada bulan April dan pengujian sampel serta analisis data lainnya dilakukan pada bulan Mei hingga Juli 2018.

Spray dibuat dengan cara merendam 200 gram daun tanaman Ageratum conyzoides yang sudah dikeringkan dan digiling hingga halus dengan etanol 96\% sebanyak $750 \mathrm{ml}$ selama 24 jam kemudian disaring dan diulangi selama 3 kali, kemudian hasil maserasi dibuat ekstrak kental dengan Rotary Evaporator, kemudian ekstrak kental $200 \mathrm{mg} / \mathrm{kg}$ dilarutkan dalam alkohol 10\% dan dimasukkan kedalam botol spray. Induksi DM pada hewan coba yaitu dengan cara mencit diaklimatisasi di kandang dengan suhu $24 \circ \mathrm{C} \pm 1{ }^{\circ} \mathrm{C}$ dan kelembapan $55 \% \pm 5 \%$, dengan 12 jam light-dark cycle (terang pada 08.00 dan gelap pada 20.00) (Wu dan Huan, 2008). Induksi Alloxan dilakukan satu kali dengan cara injeksi secara intraperitoneal alloxan monohydrate $175 \mathrm{mg} / \mathrm{kg}$ berat badan dalam 0.1 M sodium citrate buffer (pH 4.5). Kemudian mencit dibagi menjadi 5 kelompok perlakuan A (Non-diabetes + luka dan infeksi), B (Ulkus diabetikum + infeksi ), C (Ulkus diabetikum + infeksi + spray 1 kali sehari), D (Ulkus diabetikum + infeksi + spray 2 kali sehari), dan E (Ulkus diabetikum + infeksi + spray 3 kali sehari).

Pembuatan luka pada mencit dilakukan dengan cara penghilangan rambut bagian dorsal dengan pemakaian jaket pada area dorsal yang dibuat dari plester perekat, kemudian pembuatan luka dengan panjang 1 cm pada dorsal dengan menggunakan gunting dan pisau bedah. Infeksi bakteri dilakukan dengan cara inokulasi bakteri Staphylococcus aureus dengan konsentrasi $106 / \mathrm{ml}$ pada luka yang telah dibuat dengan menggunakan syringe $1 \mathrm{~mL}$. Didukung dengan uji zona hambat bakteri Staphylococcus aureus dengan ekstrak Ageratum conyzoides L. Pengaplikasian spray pada mencit ulkus diabetikum dilakukan selama 9 hari, kemudian dilakukan pengamatan histologi dermal pada ulkus diabetikum dengan pewarnaan HE pada tiap kelompok. 
Berdasarkan pengujian spray Ageratum HASIL DAN PEMBAHASAN

conyzoides L. terhadap mencit ulkus

\begin{tabular}{llll}
$\mathbf{3}$ & $\mathrm{C}$ & 307 & 288 \\
$\mathbf{4}$ & $\mathrm{D}$ & 238 & 306 \\
$\mathbf{5}$ & $\mathrm{E}$ & 179 & 388 \\
\hline
\end{tabular}

Sumber: Data Penelitian 2018

Dari tabel di atas menunjukkan bahwa spray tersebut berpengaruh terhadap penyembuhan luka mencit ulkus diabetikum. Hasil kadar glukosa darah mencit setelah induksi alloxan disajikan dalam tabel 1.

Tabel 1. Kadar Glukosa Darah Mencit Setelah Induksi Alloxan.

\begin{tabular}{cccc}
\hline \multirow{2}{*}{ No } & \multirow{2}{*}{ Kelompok } & \multicolumn{2}{c}{$\begin{array}{c}\text { Kadar Glukosa Darah } \\
\text { (mg/dL) }\end{array}$} \\
\cline { 3 - 4 } & & Hari ke-3 & Hari ke-12 \\
\hline $\mathbf{1}$ & A & 97 & 112 \\
$\mathbf{2}$ & B & 255 & 241 \\
\hline
\end{tabular}
kadar glukosa darah mencit jauh di atas normal, sehingga setiap kelompok yang diinduksi alloxan menunjukkan kondisi diabetes melitus. Kadar glukosa darah normal mencit (Mus musculus) adalah 75-140 mg/dL.

Setelah 7 hari aplikasi spray pada mencit ulkus diabetikum menunjukkan penurunan pada kelompok perlakuan spray yang tertera pada Gambar 1.

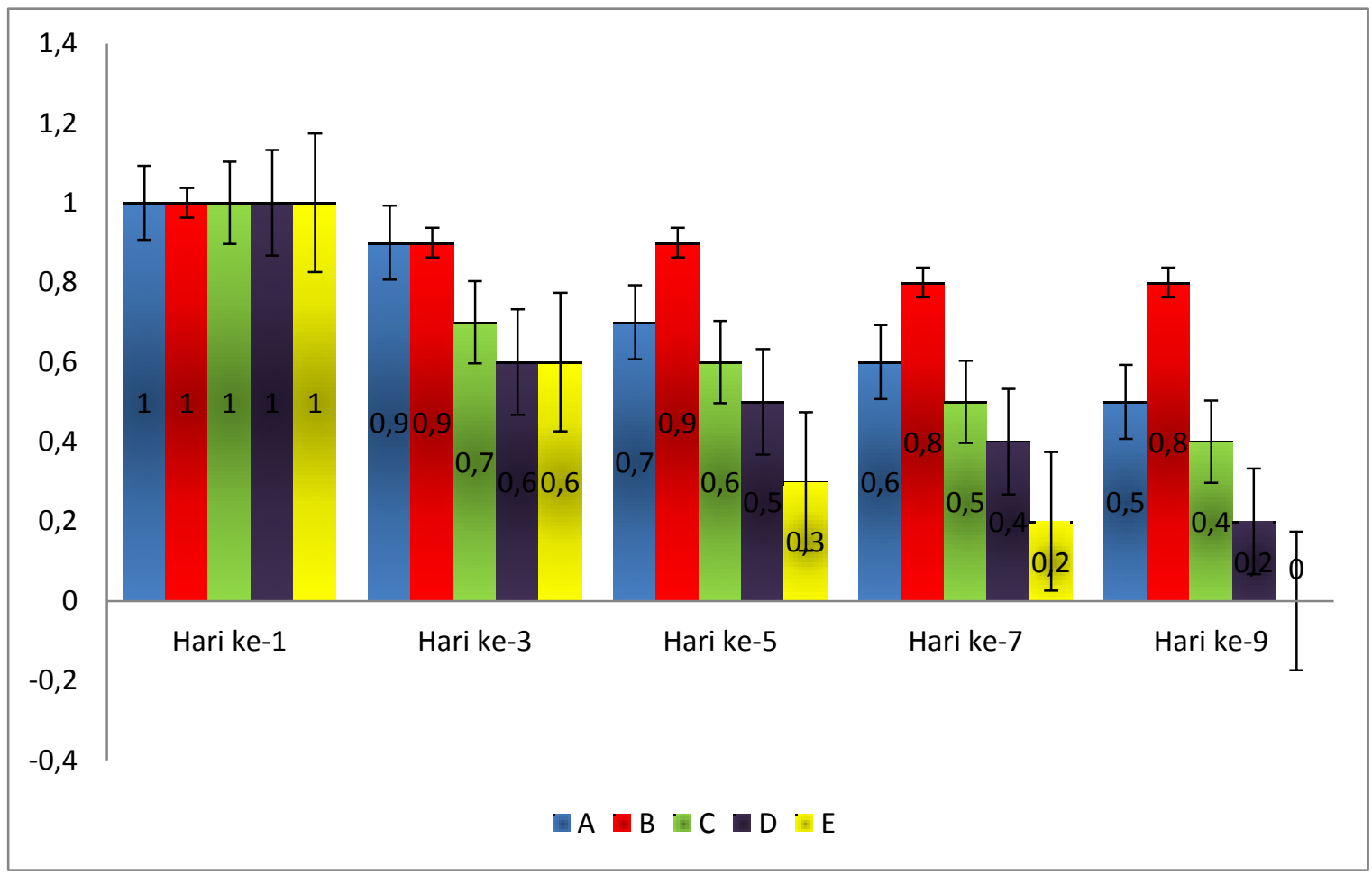

Gambar 1. Panjang Luka (cm) Mencit Ulkus Diabetikum Setelah Pemberian Spray. A (Nondiabetes + luka dan infeksi), B (Ukus diabetikum + infeksi ), C (Ulkus diabetikum + infeksi + 
spray 1 kali sehari), D (Ulkus diabetikum + infeksi + spray 2 kali sehari), dan E (Ulkus diabetikum + infeksi + spray 3 kali sehari).

Penggunaan spray daun Ageratum pembentukkan jaringan granular dan conyzoides L dalam penelitian ini, epitelisasi (Gupta et al., 2010). Kandungan dikarenakan daun Ageratum conyzoides L. aktif flavonoid yang mempunyai efek sebagai memiliki kandungan metabolit sekunder anti-inflamasi, saponin dengan manfaat yaitu alkaloid, flavonoid dan saponin yang sangat tinggi (Amadi et al., 2012), senyawa alkaloid dapat meningkatkan proliferasi seluler pada lokasi luka dan berkontribusi banyak dalam proses penyembuhan luka dengan cara mengurangi gejala inflamasi (menghambat eritema dan edema), anti mikroba, mempengaruhi kolagen, serta memperbaiki dan menguatkan sel-sel kulit (Gambar 2) regenerasi dermal dan epidermal dini, serta (Sartika, 2010).

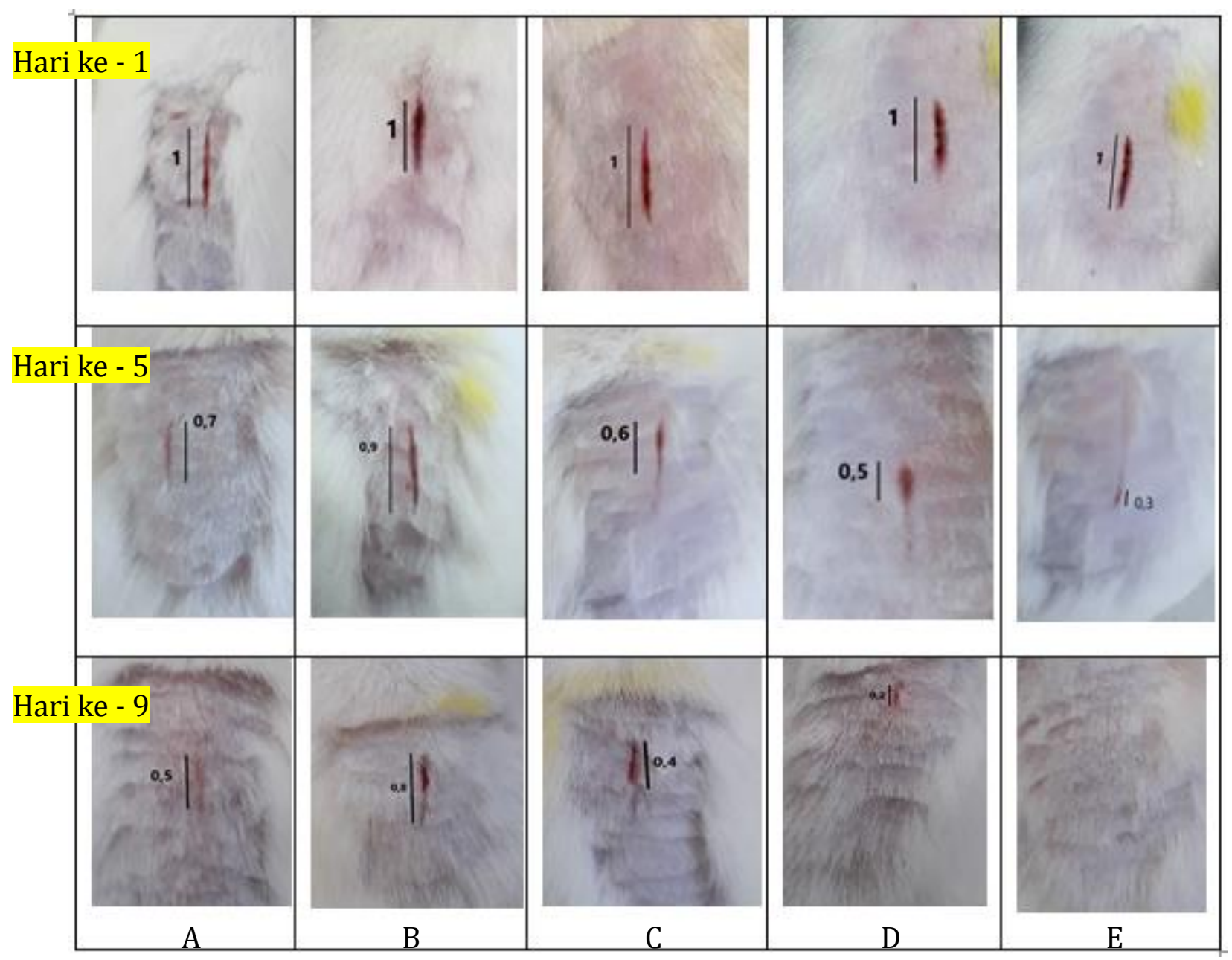

Gambar 2. Ulkus Diabetikum hari ke-1, hari ke-5 dan hari ke-9 
Selain pengukuran panjang luka pada mencit, terdapat data uji zona hambat bakteri Staphylococcus aureus terhadap ekstrak daun Ageratum conyzoides L. yang tertera pada Gambar 3.

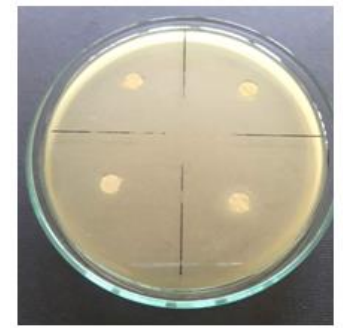

(a)

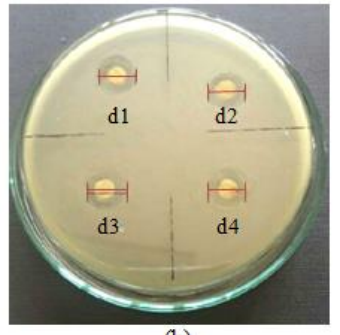

(b)
Gambar 3. Hasil Uji Zona Hambat Bakteri Staphylococcus aureus terhadap ekstrak daun Ageratum conyzoides L. (a) Bakteri Staphylococcus aureus tanpa pemberian ekstrak, (b) Bakteri Staphylococcus aureus dengan pemberian ekstrak Ageratum conyzoides L. 15\% dengan diameter zona hambat d1: 3,4 mm; d2: 3,5 mm; d3: 3,8 mm; $\mathrm{d} 4: 3,4 \mathrm{~mm}$.

Data yang diperoleh menunjukkan bahwa ekstrak etanol daun Ageratum conyzoides L. juga berpotensi menjadi antibakteri Staphylococcus aureus, didukung dengan adanya pembentukan zona hambat rata-rata sebesar 3,02 $\mathrm{mm}$.

Penelitian lain oleh Astuti (2015) menunjukkan bahwa ekstrak etanol Ageratum conyzoides L. memiliki aktivitas sebagai antibakteri terhadap Staphylococcus aureus dengan KHM pada kadar 12,5 mg/ml. Sugara (2011) menyebutkan bahwa diameter zona hambat yang dihasilkan oleh ekstrak air, metanol dan heksan daun tanaman bandotan terhadap S. aureus tergolong tinggi.

Spesimen tiap kelompok perlakuan dilakukan pemeriksaan histopatologi dengan pewarnaan Hematoxylin-eosin dengan menggunakan mikroskop cahaya perbesaran 100x.

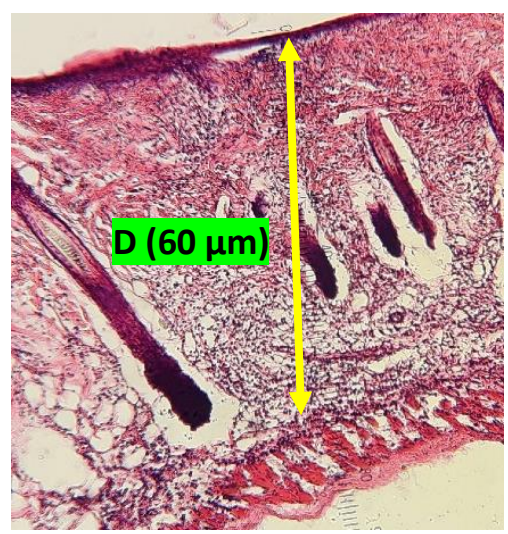

Gambar 4. (Perbesaran 100x) Histologi Dermal Kelompok A (Non-diabetes tanpa pemberian spray). Keterangan: sayatan

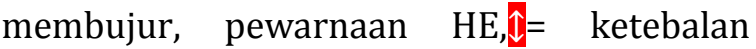
dermis.

Jaringan dermis pada kelompok luka non-diabetes hari ke-9 berukuran $60 \mu \mathrm{m}$. Hal ini dipengaruhi oleh ketebalan sel fibroblas dan kolagen yang diproduksi jaringan untuk pemulihan luka. Fibroblas merupakan sel utama selama fase proliferasi yang berperan dalam menyediakan matriks ekstraseluler sebagai kerangka untuk migrasi keratinosit yang (Gurtner dan Wong, 2007). 


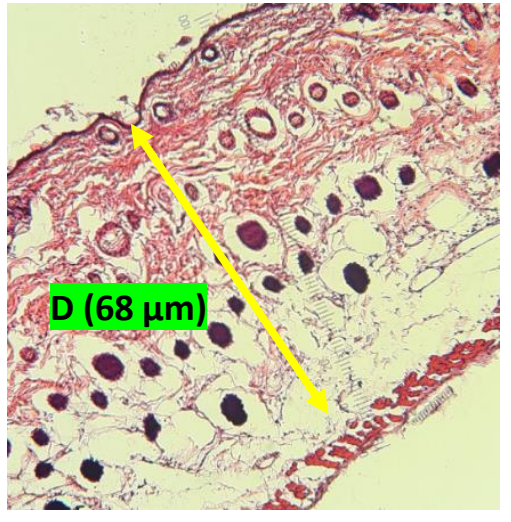

Gambar 5. (Perbesaran 100x) Histologi Dermal Kelompok Diabetes tanpa pemberian spray. Keterangan: sayatan membujur, pewarnaan $\mathrm{HE}, \mathbb{\downarrow}=$ ketebalan dermis.

Ukuran jaringan dermis pada kelompok luka diabetes tanpa pemberian spray menunjukkan ketebalan $65 \mu \mathrm{m}$. Hal ini dikarenakan pada kondisi diabetes, hipoksia menjadi lebih lama dari keadaan normal dan menghambat sel fibroblas serta imunitas sel menurun (Guo \& DiPietro, 2010). Sehingga mempengaruhi pemulihan sel pada jaringan dermis.

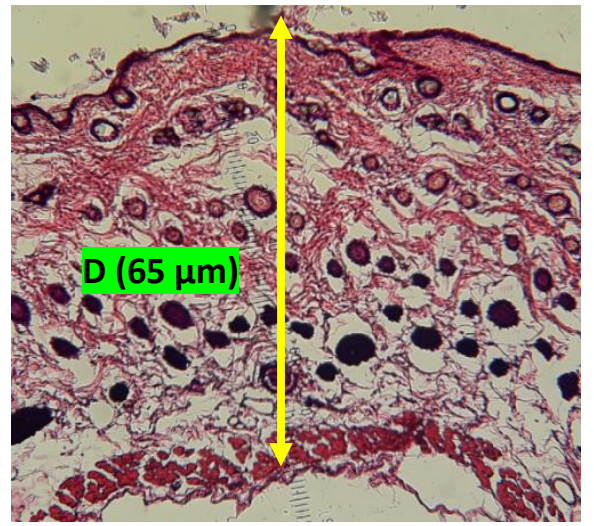

Gambar 6. (Perbesaran 100x) Histologi Dermal Kelompok Diabetes dengan pemberian spray 1 kali sehari. Keterangan: sayatan membujur, pewarnaan $\mathrm{HE}, \mathbb{\downarrow}=$ ketebalan dermis.

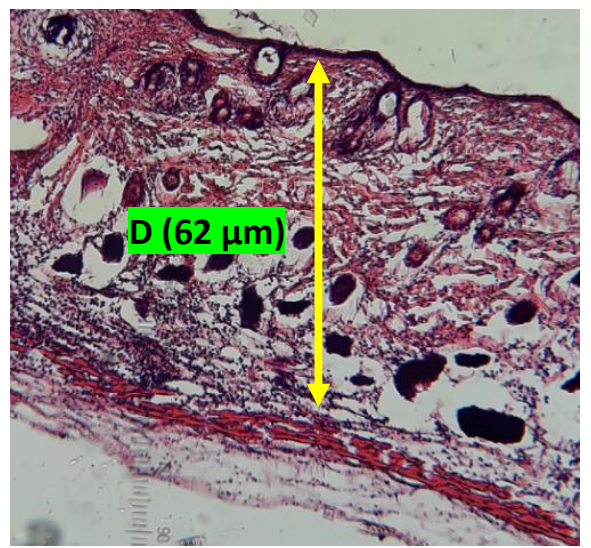

Gambar 7. (Perbesaran 100x) Histologi Dermal Kelompok Diabetes dengan pemberian spray 2 kali sehari. Keterangan: sayatan membujur, pewarnaan $\mathrm{HE}, \mathbb{\downarrow}=$ ketebalan dermis.

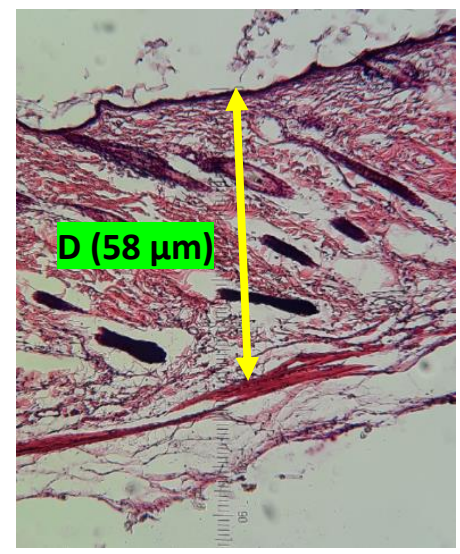

Gambar 8. (Perbesaran 100x) Histologi Dermal Kelompok diabetes dengan pemberian spray 3 kali sehari perbesaran 100x. Keterangan: sayatan membujur, pewarnaan HE, $\mathbb{\downarrow}=$ ketebalan dermis.

Gambaran histologis kesembuhan luka diabet hari ke-9 dengan penggunakan spray 3 kali sehari pada lapisan dermis memiliki struktur dermis yang lebih baik dibandingkan dengan kelompok lain yang ditandai dengan adanya folikel rambut dan sel fibroblas yang telah mengalami reorganisasi membentuk anyaman. (Dellman and Brown, 1992). 
Sehingga hasil penelitian ini dapat merekomendasikan daun bandotan dapat digunakan sebagai pengobatan luka diabetik pada kulit mencit.

Penambahan bakteri Staphylococcus aureus akan menyebabkan proses infeksi. Kondisi infeksi pada luka akan menghambat proses penyembuhan luka dan memperpanjang fase inflamasi. Semakin panjangnya fase inflamasi memicu terdegradasinya faktor pertumbuhan. Bakteri juga dapat membentuk lapisan biofilm, yaitu suatu lapisan yang menyebabkan bakteri menjadi semakin resisten sehingga proses penyembuhan luka terhambat.

Penghambatan penyembuhan luka oleh diabetes merupakan suatu mekanisme patofisiologi yang kompleks. Pada kondisi diabetes, hipoksia menjadi lebih lama dari keadaan normal. Kondisi ini menyebabkan naiknya jumlah radikal oksigen. Senyawa ini diketahui dapat menyebabkan kerusakan pada jaringan. Selain itu, perpanjangan masa hipoksia juga menyebabkan penurunan jumlah VEGF (Vascular Endothelial Growth Factor), akibatnya proses angiogenesis terganggu. Diabetes juga mengakibatkan disfungsi sel fibroblas dan epidermal serta imunitas sel $\mathrm{T}$, kemotaksis leukosit, dan fagositosis sehingga pembersihan luka dan bakteri menjadi tidak efektif dan proses penyembuhan luka terhambat (Guo \& DiPietro, 2010).

Pada penelitian ini dilakukan perbandingan waktu penyembuhan ulkus diabetikum. Panjang luka berkurang pada hari ke lima pemberian spray, panjang luka awal adalah $1 \mathrm{~cm}$, pemberian spray 1 kali sehari pada hari ke lima mengalami penurunan menjadi $0,6 \mathrm{~cm}$, pemberian spray2 kali sehari pada hari ke lima mengalami penurunan menjadi $0,5 \mathrm{~cm}$, dan pemberian spray 3 kali sehari pada hari ke lima mengalami penurunan menjadi $0,3 \mathrm{~cm}$.. Dari hasil analisis menunjukkan bahwa kemampuan daun Ageratum conyzoides L terbukti dapat mempercepat waktu penyembuhan luka bersih dalam hal ini yang diamati adalah waktu yang diperlukan warna kulit kembali normal dan panjang luka semakin menurun. Kemampuan tersebut ditunjukkan oleh kandungan metabolit sekunder yang terdapat pada daun Ageratum conyzoides yang sangat mendukung dalam proses penyembuhan luka.

Zat aktif Flavonoid diduga mempunyai efek menurunkan jumlah hari masa inflamasi atau sebagai anti-inflamasi dengan melancarkan peredaran darah ke seluruh tubuh dan mencegah terjadinya penyumbatan pada pembuluh darah, berfungsi juga sebagai anti-oksidan dan membantu mengurangi rasa sakit jika terjadi pendarahan atau pembengkakan (Hustiantama, 2002). Flavonoid merupakan senyawa yang diketahui memiliki aktivitas sebagai antioksidan karena kemampuannya untuk mendonorkan proton kepada senyawa yang tidak stabil sehingga menjadi stabil (Stocks et al, 1974). Flavonoid bersifat 
antioksidan yang dapat menstabilkan ROS sehingga tidak menyerang sel dan tidak menghambat proses angiogenesis. Hal ini akan mempercepat penyembuhan luka. Mekanisme flavonoid dalam penyembuhan luka adalah dengan meningkatkan proliferasi sel epitel dan kolagen sehingga proses penyembuhan luka menjadi lebih baik (Muralidhar et al., 2013).

Golongan senyawa alkaloid diketahui dapat mempercepat proses penyembuhan luka. Alkaloid dapat menginisiasi fibroblas menuju daerah luka (Reyes et al., 1993). Fibroblas merupakan salah satu komponen penting dalam penyembuhan luka. Dengan kehadiran fobroblas yang semakin banyak, maka proses penyembuhan luka akan semakin cepat (Diegelmann \& Evans, 2004).

Saponin yang merupakan golongan triterpenoid diidentifikasi memiliki manfaat yaitu mengurangi gejala inflamasi (menghambat eritema dan edema), anti mikroba, mempengaruhi kolagen, serta memperbaiki dan menguatkan sel-sel kulit. Daun dewa sebagai anti koagulan dan melancarkan sirkulasi darah (Sartika, 2010). Mekaniseme kerja lain dari saponin dalam penyembuhan luka adalah menstimulasi pembentukan kolagen tipe 1 yang berperan penting dalam proses penutupan luka dan meningkatkan epitelisasi jaringan. selain itu juga sebagai antimikroba, antioksidan dan mempercepat migrasi sel epitel (Miladiyah dan Prabowo, 2012).
Penelitian lain oleh Sachin et al. (2009) menunjukkan bahwa ekstraksi dari akar Ageratum conyzoides memiliki senyawa alkaloid yang mampu mempercepat epiteliasi kulit tikus albino. Mustafa et al. (2005) mengatakan bahwa perpaduan ekstrak daun Ageratum conyzoides dan madu dapat mempercepat penyembuhan luka pada tikus.

\section{KESIMPULAN}

Berdasarkan hasil penelitian, diperoleh simpulan bahwa pemberian spray Ageratum conyzoides $\mathrm{L}$. berpengaruh pada penurunan panjang luka diabetik mencit. Perlakuan spray 3 kali sehari paling berpengaruh dibandingkan dengan perlakuan yang lain yaitu yaitu mengalami penutupan luka dalam 9 hari dan presentase sel nekrosis 18\%. Dengan demikian, spray daun Ageratum conyzoides L. berpotensi untuk terapi ulkus diabetikum yang terinfeksi Staphylococcus aureus.

Untuk penelitian selanjutnya diharapkan dapat memperoleh data presentase sel yang mengalami nekrosis agar dapat memperkuat potensi ekstrak daun bandotan dalam memulihkan luka diabetik mencit yang terinfeksi Staphylococcus aureus.

\section{DAFTAR PUSTAKA}

Amadi, B., Duru M, dan Agomuo E. 2012. Chemical profilesof leaf, stem, root and flower of Ageratum conyzoides. Asian Journal of Plant Science and Research. 2 (4): 428-432.

Arianingsih, EP., Uno, WD. and Kumaji, SS. 2015. Pengaruh Ekstrak Daun Tanaman Yodium (Jatropha Multifida L.) 
Terhadap Pertumbuhan Bakteri Staphylococcus aureus. Univ Negeri Gorontalo Fak Mat Dan Ipa Jur Biol. $3 p$.

Astuti, H. 2015. Uji Aktivitas Antibakteri Ekstrak Etanol Dan Ekstrak Air Daun Bandotan (Ageratum conyzoides, L.) Terhadap Staphylococcus aureus Dan Escherichia coli. Majalah Farmaseutik. 11(1): 290-293.

Broughton, GG., Janis, JE. and Attinger, CE. 2006. Wound healing: an overview. Plast Reconstr Surg, 117(7 Suppl).

Diegelmann, RF., and Evans, MC. 2004. Wound Healing : An Overview of Acute, Fibrotic and Delayed Healing. Bioscience. 9: 283-289.

Guo, S., and DiPietro, LA. 2010. Oxidative Stress and Diabetic Complications Circ. Res. 107(9): 1058-1070.

Gupta, N dan Jain UK. 2010. Prominent wound healing properties of indigenous medicines. $J$ Nat Pharmaceutic. 2010(1) :2-10.

Gurtner, GC. and Wong, VW., 2007. Wound healing: normal and abnormal.Grabb and Smith's plastic surgery. 6: 15-22.

Hastuti, RT. 2008 . Faktor-Faktor Risiko Ulkus Diabetes pada Penderita Diabetes Mellitus (Studi Kasus Di RSUD Dr. Moewardi Surakarta). Semarang: Universitas Diponegoro, Program Studi Magister Epidemiologi, Program Pasca Sarjana.

Igafur, RHR., Ayu, WD., and Masruhim, MA. 2016. Uji Aktivitas Ekstrak Metanol Daun Bandotan (Ageratum Conyzoides Linn.) Terhadap Penyembuhan Luka Bakar Pada Tikus Putih (Rattus norvegicus). InProceeding of Mulawarman Pharmaceuticals Conferences. 3: 335-339).

Kementrian Kesehatan RI. 2017. Tahun 2030 Prevalensi Diabetes Melitus Di Indonesia Mencapai 21,3 Juta Orang.
Depkes.go,online

(http://www.depkes.go.id diakses pada tanggal 19 Sep. 17).

Mahibalan, S., Stephen, M., Nethran, RT., Khan, R. and Begum, S. 2016. Dermal wound healing potency of single alkaloid (betaine) versus standardized crude alkaloid enriched-ointment of Evolvulus alsinoides. Pharmaceutical biology. 54(12): 2851-2856.

Miladiyah, I., Prabowo, BR. 2012. Ethanolic Extract of Anredera cordifolia (Ten.) Steenis Leaves Improved Wound Healing in Guinea Pigs. Univ Med. 31(1) : 4-11.

Muralidhar, A., Babu, KS., Sankar, TR., Reddanna, P., dan Latha, J. 2013. Wound Healing Activity of Flavonoid Fraction Isolated From the Stem Bark of Butea monosperma (lam) in Albino Wistar Rats. European Journal of Experimental Biology. 3(6): 1-6.

Mustafa, MR., Mahmood, AA., Sidik, K. and Noor, SM. 2005. Evaluation of wound healing potential of Ageratum conyzoides leaf extract in combination with honey in rats as animal model. Int J Mol Med Adv Sci. 1(4): 406-410

Reyes, BHP., Lewis, WH., Roman, J., Simchowitz, L., dan Mustoe, TA. 1993. Enhancement of Wound Healing by The Alkaloid Taspine Defining Mechanism of Action. Exp Biol Med. 203(1): 18-25.

Sachin, J., Neetesh, J., Tiwari, A., Balekar, N. and Jain, DK. 2009. Simple evaluation of wound healing activity of polyherbal formulation of roots of Ageratum conyzoides Linn. Asian J Res Chem. 2(2): 135-138.

Sartika, DD. 2010. Efek lumatan daun dewa (Gynura segetum) dalam memperpendek waktu penyembuhan luka bersih pada tikus putih. Jurnal Keperawatan Soedirman, 5(3): 127-135.

Smeltzer, SC., dan Bare BG. 2008. Buku Ajar Keperawatan Medikal Bedah Brunner \& Suddarth. Jakarta: EGC. 
Stocks, J., Gutteridge JM., Sharp RJ., dan Doemandy TL. 1974. The Inhibition of Lipid Autoxidation by Human Serum and Its Relation To Serum Proteins and Tocopherol. Clin Sci Mol Med. 47: 223233.

Sugara, TH., 2011. Karakterisasi Senyawa Aktif Antibakteri Dari Fraksi Etil Asetat Daun Tanaman Bandotan (Ageratum conyzoides L.).

O'Brien, M. 2002. Exploring methods of wound debridement. British journal of community nursing. 7(3): 1018. 